\title{
MEMÓRIA DA ABOLIÇÃo NA MAÇONARIA PAULISTA
}

Renata Ribeiro Francisco

\section{Resumo}

O presente artigo tem o objetivo de analisar a construção da memória da abolição na maçonaria paulista. Para este estudo examinou-se o modo pelo qual as representações dos maçons se articularam com o desejo de construção da memória maçônica da abolição no espaço público. Num primeiro momento, realizou-se a contextualização dos caminhos percorridos pela maçonaria paulista em sua ascensão, decadência e sucessiva luta pela recuperação de sua memória na história do Brasil. Em seguida, discutiu-se como a maçonaria tem construído um lugar de memória na cidade de São Paulo. Por fim, analisou-se a emergência de uma literatura maçônica, denominada celebrativa, na década de 1970, cujo objetivo era difundir e consolidar as narrativas positivas e evocativas da organização maçônica.

Palavras-chave: Memória; maçonaria; literatura maçônica; São Paulo.

\begin{abstract}
This article aims to analyze the construction of the memory of abolition in São Paulo Freemasonry. For this study we examined the way in which the representations of Freemasons articulated with the desire to construct the Masonic memory of abolition in public space. At first, the contextualization of the paths taken by the Paulista Freemasonry in its ascension, decay and successive struggle for the recovery of its memory in the history of Brazil was realized. Then it was discussed how Freemasonry has built a place of memory in the city of Sao Paulo. Finally, the emergence of a Masonic literature called celebrative in the 1970s was analyzed and its aim was to disseminate and consolidate the positive and evocative narratives of the Masonic organization.
\end{abstract}

Keyword: Memory; masonic; masonic literature; São Paulo.

\section{Introdução}

Desde meados da década de 1950, a maçonaria brasileira tem se valido de um conjunto de estratégias com o propósito de resgatar a memória maçônica e difundir uma imagem positiva da instituição (MOREL; SOUZA, 2008, p. 222). Nesse processo os pesquisadores maçônicos não apenas privilegiaram as biografias de personagens históricos ligados à organização, como recorreram a outros recursos instrumentalizados pela maçonaria. A maçonaria reivindica para si o protagonismo em, ao menos, três eventos históricos importantes ocorridos no país: a independência política do Brasil, a abolição da escravidão e a instauração da República. 


\subsection{A luta pela recuperação da memória maçônica}

Ao final do século XIX, a maçonaria consolidou-se como organização civil de grande prestígio capaz de influenciar as decisões políticas do país. Prova disso foi a constituição do primeiro ministério do governo republicano de Deodoro da Fonseca, composto, em sua maioria, por maçons (Quintino Bocaiúva, ministro dos Transportes; Aristides Lobo, ministro do Interior; Benjamin Constant, ministro da Guerra; Rui Barbosa, ministro da Fazenda; Campos Sales, ministro da Justiça; Eduardo Wandenkolk; ministro da Marinha; e Demétrio Ribeiro, ministro da Agricultura) (BARATA, 1999). Deodoro da Fonseca, durante o exercício da presidência chegou a ocupar simultaneamente o cargo de grão-mestre do Grande Oriente do Brasil. Conforme Barata,

(...) uma análise da relação dos 85 nomes que compunham os gabinetes ministeriais, entre 1870 e 1889, revelou que aproximadamente $13 \%$ deles pertenciam ou pertenceram à Maçonaria. Já no Conselho de Estado este percentual aumentava para 30\% dos 48 conselheiros no mesmo período. Por sua vez, a relação dos 77 senadores vitalícios das seis províncias mais importantes do Império - Rio de Janeiro, Minas Gerais, Rio Grande do Sul, São Paulo, Bahia e Pernambuco - revelou um percentual aproximado de $21 \%$ de maçons (BARATA, 1999, p. 138).

Não por acaso, nos primeiros anos de vigência da República, a maçonaria beneficiou-se de uma série de medidas instituídas pelo governo. A primeira delas, talvez a mais importante, tratou-se da decretação do fim do padroado, instituída pela Lei de 7 de janeiro de 1890, que estabeleceu o Estado laico no país. A medida atendia particularmente a um antigo desejo maçônico que tinha a Igreja católica como sua principal inimiga. O afastamento da Igreja das esferas de poder viabilizou a implantação de um projeto educacional laico e o enfraquecimento do domínio religioso sobre outras esferas da sociedade civil, embora não tivesse havido consenso maçônico sobre outros temas, como por exemplo, o posicionamento da organização no que dizia respeito ao tema da abolição. Esse período áureo de expansão vivenciado pela maçonaria no Brasil, logo seria interrompido com a ascensão de Getúlio Vargas ao poder. Durante o governo getulino a maçonaria perderia espaço na cena política e deixaria de ser uma organização civil influente como fora outrora.

A ascensão de Getúlio Vargas, em 1930, somada a uma nova configuração socioeconômica engendrada com a emergência da burguesia industrial, operariado e exército, desencadearia novas demandas e interesses, que seriam suprimidos por duas novas ideologias: o integralismo, como expressão dos grupos conservadores de direita, representada pela Igreja católica e pela própria figura de Getúlio Vargas, e o comunismo, como ideologia endereçada, sobretudo, aos movimentos operários. Essas novas correntes de pensamento amplamente ventiladas no cenário internacional 
encontraram espaço fértil de disseminação no Brasil dentro desse contexto. O integralismo, como é sabido, se transformaria numa das principais bases de apoio do governo até 1937 (SANTOS; 1934).

Simpatizante do integralismo, Getúlio Vargas se apropriou dessa ideologia repelindo e perseguindo, em contrapartida, o comunismo. O integralismo admirado por Vargas, difundido no Brasil, pregava o nacionalismo exacerbado, o antissemitismo e o antimaçonismo.

Esse último, o antimaçonismo, foi um dos elementos que aproximou a Igreja católica do governo, que, por sua vez, ensaiava, desde a década de 1920, o seu retorno à esfera política. A união dessas forças sociais e ideológicas acabariam atuando de modos distintos para minar o poder da maçonaria. A Igreja católica, por exemplo, em sua luta para reivindicar um lugar no projeto político varguista não hesitou em apoiar Getúlio Vargas antes mesmo que ele alcançasse o poder. Vargas era o candidato da Igreja católica e o arcebispo Dom Leme liderou e articulou o movimento religioso de apoio ao candidato . Assim, com a ascensão de Getúlio ao poder, em 1930, a Igreja católica não teria grandes dificuldades em propor uma aliança com o novo governo. Pelo contrário, durante o governo provisório (1930-1934), a instituição rapidamente acionou o Ministro da Educação, Francisco Campos, a fim de concretizar as reivindicações católicas para a educação, muitas delas vistas como retrocesso pela maçonaria, então, defensora do Estado laico e da educação livre da influência religiosa (GOHL, 2003).

A reinserção da Igreja católica na cena política seria o primeiro grande passo contra a maçonaria. O segundo viria pouco tempo depois, quando Getúlio Vargas promoveu a interrupção das atividades maçônicas ${ }^{1}$. Oito meses depois do encerramento dos trabalhos, o grão-mestre Moreira Guimarães, do Grande Oriente do Brasil promulgou o decreto $n^{\circ} 1.179$, a 2 de junho de 1938, que determinava que as lojas maçônicas excluíssem de seu quadro os Irmãos que professassem ideologias contrárias ao regime político-social brasileiro. Com a medida, a maçonaria exprimiu o desejo de ser vista como aliada do novo governo, dispondo-se a respeitar a nova constituição. Assim, incorporou alguns elementos que eram compatíveis com os interesses ideológicos do governo, afastando qualquer indício de associação da organização ao comunismo e ao judaísmo internacional. Na avaliação de Alexandre Barata, desde meados do século XVIII, a Igreja vinha perseguindo a maçonaria, atribuindo a ela "uma natureza subversiva, cujo principal desejo era depor os próprios governantes” (GOHL, 20003, p.172). A propaganda antimaçônica, segundo o autor, foi sistematizada nas primeiras décadas do século XIX “a partir da publicação de obras, folhetos, impressos dedicados a combater o expansionismo maçônico” (BARATA, 1999,

1 Em 24 de outubro de 1937, o Conselho de Segurança Nacional suspendeu as atividades regulares da maçonaria, apreendendo os arquivos de todas as lojas. 
p.198). Nesse cenário emergiu a teoria do complô, no qual a maçonaria passa a ser vista como organização responsável por difundir o semitismo e o comunismo.

A promulgação do decreto $\mathrm{n}^{0} 1.179$, no qual a maçonaria se comprometia a expor a identidade de seus membros, bem como suas respectivas ideologias, contribuiu para a organização deixasse de ser alvo central da perseguição do Estado, retomando suas atividades lentamente a partir de 1938 (GRAINHA, s.d). Contudo, mesmo após a regularização dos trabalhos na década de 1940, o governo de Getúlio Vargas manteve forte fiscalização sobre as atividades da organização, obrigando as lojas maçônicas a fornecerem local, data e hora das reuniões, além de disponibilizar toda a documentação relativa ao controle de registros dos pedreiros-livres iniciados e filiados.

A forte fiscalização, aos poucos, minaram a autonomia maçônica, diminuindo consequentemente, sua visibilidade social e política. A Loja Piratininga, por exemplo, registrava em ata de 1940 as dificuldades em retomar às atividades da loja depois da apreensão de seus arquivos.

Da orientação política integralista do governo Vargas aos tradicionais conflitos entre a Igreja católica e a maçonaria nasceria uma forte política antimaçônica. Esse movimento antimaçônico engendrado pela teoria do complô e difundido pelos integralistas afirmava que a maçonaria, ao lado do judaísmo e do comunismo, formava uma frente disposta a realizar uma conspiração liberal universal para destruir a Igreja católica e o governo.

Movida pelos conflitos e rivalidades seculares travadas contra a maçonaria, a Igreja católica acabou aderindo e alimentando o discurso antimaçônico. Gustavo Barroso tornou-se um dos principais porta-vozes do combate à maçonaria. O livro de Gustavo Barroso, História Secreta do Brasil , publicado em 1938 e composto por seis volumes, veio nutrir a literatura antimaçônica. A obra ganhou ampla repercussão e se transformou no principal veículo de divulgação da teoria do complô maçônico no país entre as décadas de 1930 e 1940.

A ampla circulação dos títulos de Barroso, sobretudo de seu livro História secreta do Brasil, ganhou ainda mais visibilidade em decorrência da militância política do escritor junto à Ação Integralista Brasileira, ao lado de Plínio Salgado. Nesse cenário, a obra de Barroso encontraria espaço propício à difusão da ideologia integralista baseada na condenação à maçonaria, ao judaísmo internacional e ao comunismo.

Em História Secreta do Brasil, Gustavo Barroso constrói uma narrativa da história do país salientando o obscurantismo das sociedades secretas (carbonária, bucha e maçonaria), que em diferentes contextos, segundo sua percepção, atentaram contra o Estado. Conforme Barroso, como organização secreta, a maçonaria conseguia infiltrar-se com facilidade em diversos espaços de 
poder, como a imprensa e os altos cargos governamentais:

Se o maçonismo-bucheiro não conseguisse o poder pelas armas, lá se ia de água abaixo o longo trabalho de desagregação liberal do Brasil. E a reação armada contra o que os jornais liberais maçonizados chamavam o regresso viria de Piratininga, foco da Bucha, das montanhas mineiras, foco da maçonaria (BARROSO, 1993, p.18).

A perda de visibilidade maçônica na historiografia foi muito bem desenhada na análise de Célia Maria Marinho de Azevedo em seu livro Maçonaria, Anti-Racismo e Cidadania. Num dos tópicos do estudo, por meio das interpretações clássicas de Oliveira Lima, Francisco Adolfo de Varnhagen e Caio Prado Junior (AZEVEDO, 2010, p.45), diagnosticou ter havido um progressivo processo de desaparecimento da maçonaria como agente propulsor de transformações. Enquanto as obras de Oliveira Lima e Francisco Adolfo de Varnhagen, nascidos no século XIX, ressaltavam a forte presença maçônica no interior das instituições e fora dela, Caio Prado Júnior, nascido no século XX, em contrapartida, seguia diminuindo consideravelmente a notoriedade maçônica em sua interpretação. A perspectiva analítica de Azevedo convergia exatamente na direção do cenário vivido pela organização maçônica. As interpretações de Oliveira Lima e Francisco Adolfo de Varnhagen refletiam o período de consolidação e apogeu maçônico da década de 1920, ao passo que a interpretação de Caio Prado Junior parecia revelar a situação de crise e decadência vivida pela maçonaria, além de mostrar o enfraquecimento do lugar de agente político ostentado pela organização outrora.

\subsection{A memória maçônica da abolição através da construção de museus}

Diante da perda de visibilidade e de poder, a maçonaria reagiria criando o Instituto Maçônico de Propaganda e Cultura, em 1953, com o intuito de recuperar sua memória (MOREL; SOUZA, 2008, p.46). O órgão propunha uma série de medidas, dentre as quais estavam a abertura dos templos à visitação pública, a criação de bibliotecas, a construção de lugares de memória, e a compilação de uma historiografia comprometida em exaltar a memória coletiva maçônica (MOREL; SOUZA, 2008, p.57).

A reminiscência que a organização maçônica pretendia resgatar era a memória coletiva como "uma tentativa de um grupo de criar um elo positivo entre seu passado glorioso e o presente” , uma memória "que guarda[ria] do passado apenas o que possa ser útil para criar um elo entre o 
presente e o passado". Vale destacar que memória, aqui, é entendida como "seletiva”, "vulnerável” e "espontânea”, contrária à história como “uma operação profana, uma reconstrução intelectual sempre problematizadora que demanda análise e explica uma representação sistematizada e crítica do passado" (SEIXAS, 2004, p.40-41).

Sob esse prisma surgiu o museu do Grande Oriente do Brasil, denominado Ariovaldo Vulcano² $^{2}$ em 1955. O lugar então escolhido para demarcar a memória maçônica foi a antiga sede do Grande Oriente do Brasil, localizada na Rua do Lavradio, centro da cidade do Rio de Janeiro (SILVA, 2012, p. 16). Conforme o decreto $\mathrm{n}^{\circ 236}$, de 28 de maio de 1955, estabelecido pela constituição maçônica, o museu deveria comportar templos (combinado por reproduções e descrições, altares, painéis, tapetes, bandeiras, estandartes, lanternas e castiçais), objetos dos rituais (aventais, faixas, malhetes, esquadros, compassos, espadas), arte maçônica (esculturas, bustos de maçons importantes), manuscritos (originais e reproduções) e biblioteca (composta por constituições, literatura maçônica e antimaçônica) (FERREIRA, 2013, p.37) .

O objetivo do museu era construir uma memória que vinculasse o trabalho maçônico à história do Brasil (FERREIRA, 2013, 29). Conforme Pierre Nora, os "lugares de memória”3 são erguidos quando “aquilo que procuram defender se encontra ameaçado” (OLIVEIRA, 2014, p.201). No museu maçônico pertencente ao Grande Oriente do Brasil encontram-se não apenas os objetos dedicados aos rituais, tais como aventais, malhetes e castiçais, mas também artefatos produzidos com o propósito de registrar o suposto protagonismo maçônico nos eventos históricos mais importantes do país (a independência política do Brasil, a abolição e o advento da República). Embora seja possível encontrar objetos que façam referência a diferentes páginas da história do país associados à organização maçônica, nesta análise o objetivo é ilustrar especificamente os objetos que vinculam a maçonaria à memória da abolição.

Os organizadores do museu do Grande Oriente do Brasil não tardaram a elaborar uma placa em comemoração à Lei do Ventre Livre esculpida em mármore. A placa reverenciava o papel da maçonaria na aprovação da lei sancionada pelo parlamentar maçom José Maria da Silva Paranhos, o Visconde do Rio Branco (FERREIRA, 2013, p.60). Na ocasião da sanção da lei, em 28 de setembro de 1871, Rio Branco ocupava, ao mesmo tempo, um cargo no Conselho dos Ministros e o cargo de grão-mestre do Grande Oriente do Brasil. Por essa razão, a organização maçônica compreendia a

2 O decreto $\mathrm{n}^{\circ}$ 0016, de 16 de junho de 1955 nomeou o Museu.

3 A expressão "Lugar de Memória” foi elaborada por Pierre Nora na apresentação da coletânea Les lieux dês memoires. Paris: Gallimard, 1984, vol. 1, pp. 213, VII-XLII. Ver: Oliveira, Cecília Helena de Salles. Museu Paulista: espaço celebrativo e memória da independência. In: Memória e (res)sentimento: indagações sobre uma questão sensível. (Org) Stella Bresciani e Márcia Naxara. 2 Edição. Campinas, São Paulo, Unicamp: Editora Unicamp, 2014, p.195-219, p. 201. 
sanção da Lei do Ventre Livre como uma ação da vontade coletiva do grupo e não como uma tomada de posição que abarcou amplo debate e envolveu inúmeros atores políticos de diferentes orientações políticas e ideológicas presentes dentro e fora do parlamento.

O entendimento de que a Lei do Ventre Livre era fruto da ação maçônica ficou cristalizado na celebração realizada em 2 de março de 1872 com o discurso do padre maçom Almeida Martins, no ano seguinte à decretação da lei, em homenagem a Rio Branco "numa solenidade maçônica” (CASTELLANI, 1973, p.168). A decisão do padre maçom naquele momento provocaria a sua própria suspensão das atividades eclesiásticas, com desdobramentos na Questão Religiosa. A placa em homenagem a Lei do Ventre Livre não era o único objeto criado para adornar o museu . Lá também foi depositada uma réplica da pena usada pela princesa Isabel para a assinatura da Lei Áurea em 13 de maio de 1888.

\section{Figura 1 Réplica da pena usada pela princesa Isabel na assinatura da Lei Áurea}

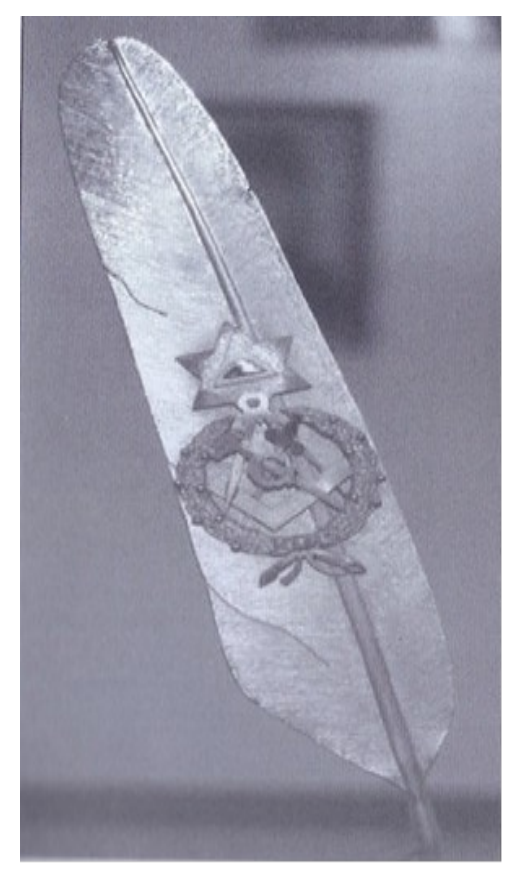

Fonte: Cláudio Roque Buono Ferreira, 2013. p. 45. (Museu do Grande Oriente do Brasil).

A réplica da pena, não datada, chama a atenção por trazer cravejado ao centro a insígnia da organização maçônica, fazendo, portanto, uma explícita alusão ao protagonismo maçônico no processo abolicionista. Conforme as narrativas da própria organização, no ato da assinatura do documento que pôs fim a quase quatrocentos anos de escravidão, a maçonaria teria participado 
ativamente desse evento histórico representado na figura do maçom abolicionista Joaquim Nabuco. De acordo com o pesquisador maçom Nicola Aslan, enquanto a Lei Áurea era "sancionada pela Princesa D. Isabel de uma sacada, Joaquim Nabuco comunicava à multidão postada em frente ao Palácio, que a escravidão estava extinta no Brasil” (ASLAN, 1973, p.530).

$\mathrm{Na}$ interpretação do autor, o papel de mensageiro exercido por Joaquim Nabuco naquele instante se equiparava ao papel desempenhado pela própria princesa Isabel, numa clara alusão ao protagonismo maçônico no evento histórico. Dessa maneira, o Grande Oriente do Brasil se apropriava da data do 13 de maio como parte integrante de sua história.

Da mesma forma que o Grande Oriente do Brasil construiu um lugar próprio de memória, o Grande Oriente de São Paulo articularia a fundação de museu demonstrando autonomia em relação ao Grande Oriente do Brasil. O projeto de criação de um museu próprio era desejo antigo da maçonaria paulista que remontava à década de 1920.

Desde a promulgação da nova constituição maçônica, em 1892, o Grande Oriente do Brasil desejava simplificar e estimular a criação de Grandes Lojas Estaduais federadas com o intuito de descentralizar o poder maçônico. As primeiras Lojas Estaduais a surgirem foram as de São Paulo e da Bahia, ambas criadas em 14 de maio de 1892. A autonomia idealizada, entretanto, parecia não atender aos interesses de muitas das lojas paulistas que, em maio de 1893, se rebelaram contra a autoridade do Grande Oriente do Brasil, dando início a uma nova dissidência. O movimento foi encabeçado pelas Lojas maçônicas América, Roma, Sete de Setembro e Harmonia \& Caridade, e, em princípio, Amizade e Piratininga. Essas duas últimas, no entanto, optaram por permanecer vinculadas ao Grande Oriente do Brasil, do vale do Lavradio.

Nesse cenário de dissidências nasceu o Grande Oriente de São Paulo , desejo latente dos maçons paulistas de demarcarem sua autonomia em relação ao Grande Oriente do Brasil. Fomentado por mais uma cisão, essa nova obediência resgataria o antigo sonho de ter um espaço próprio de memória 4 .

Essa intenção regionalista da maçonaria paulista ficaria ainda mais evidente, em razão da escolha de inaugurar seu espaço de memória na data de celebração do aniversário da cidade de São Paulo, em 25 de janeiro. Com essa iniciativa o museu dedicado à celebração do passado maçônico paulista permaneceria vinculado à própria história da cidade de São Paulo.

4 O termo monumento-museu foi empregado por Cecília Helena de Salles Oliveira com o objetivo de ilustrar o papel dos espaços edificados como lugares de memória política. da independência. In: Memória e (res)sentimento: indagações sobre uma questão sensível. OLIVEIRA, Cecília Helena de Salles. Museu Paulista: espaço celebrativo e memória. In: (Org) Stella Bresciani e Márcia Naxara. $2^{\circ}$ Edição. Campinas, São Paulo, Unicamp: Editora Unicamp, 2014, p.195-219, p. 197. 


\section{Figura 2: Museu do Grande Oriente de São Paulo}

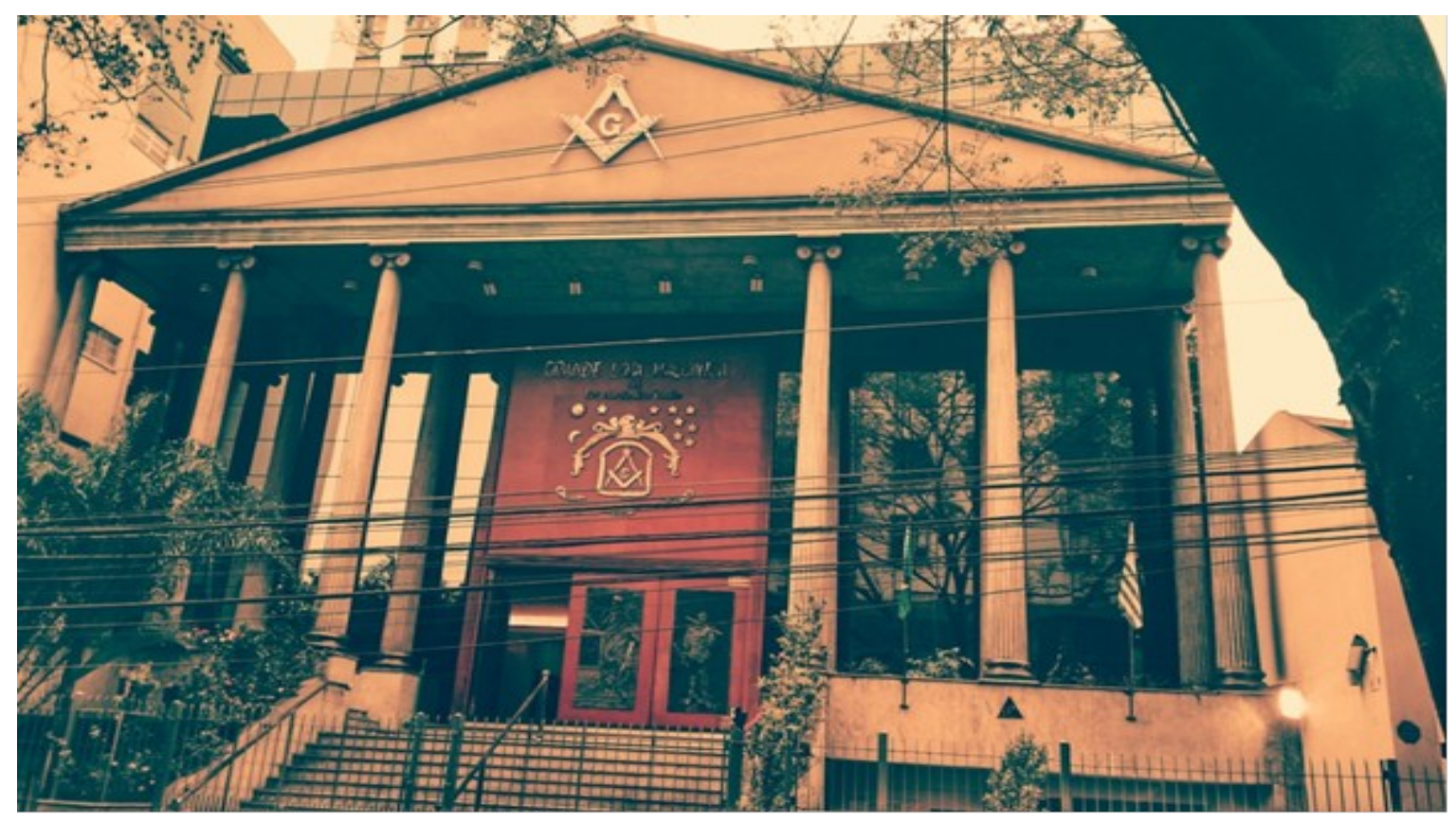

Fonte: Rua São Joaquim, cidade de São Paulo, 2016. (Arquivo pessoal)

A maçonaria paulista pretendia inaugurar o museu em 1954, porém a falta de recursos atrasou a obra em um ano. Projetado como espaço de celebração da maçonaria dessa localidade, o lugar pretendia promover as figuras de grande visibilidade que passaram pela organização, cuja história vinculava-se à cidade. José Bonifácio de Andrada foi homenageado emprestando seu nome ao museu. Ele havia sido o responsável pela criação da primeira ordem maçônica no Brasil em 1822.

A escolha da figura de Bonifácio para dar nome ao museu não foi aleatória. O maçom era um personagem de visibilidade nacional, com uma trajetória política de relevo que podia ser explorada do ponto de vista simbólico. Nascido na província de São Paulo, na cidade de Santos, Bonifácio não representava apenas a independência política do Brasil, como também a própria abolição, visto que o maçom exibira uma representação sobre a escravidão na Assembleia Geral Constituinte e Legislativa do Império em 1823. No documento, Bonifácio declarava a necessidade de colocar um ponto final na escravidão.

Outras duas figuras lembradas pelos maçons paulistas a terem suas memórias evocadas pela organização eram os maçons Luiz Gama e Américo de Campos, ambos membros republicanos da Loja América que travaram juntos lutas contra a escravidão na cidade. Luiz Gama teria a sua 
imagem gravada no museu por meio da edificação de um busto, ao passo que a hemeroteca homenagearia Américo de Campos, abolicionista e jornalista, que atuou nos bastidores dos jornais Correio Paulistano e A Província de São Paulo.

O monumento-museu erguido no interior da Grande Loja de São Paulo, à Rua São Joaquim, no Bairro da Liberdade, com vista privilegiada, atraía a admiração daqueles que por ali passavam. Sua extensa e larga escadaria tinha a função de projetar o edifício, revelando o segredo maçônico exposto por meio do seu símbolo maior, o esquadro cruzado sob o compasso à testa do edifício. Esse era o símbolo que resguardava a singularidade daquela estrutura pertencente à maçonaria (Figura 2).

O museu maçônico encontra-se fechado para reforma, por essa razão não foi possível o acesso ao espaço. Contudo, tem-se a imagem da biblioteca do museu, reproduzida no livro do maçom Cláudio Roque Buono Ferreira (figura 3).

\section{Figura 3: Biblioteca do Museu do Grande Oriente de São Paulo.}

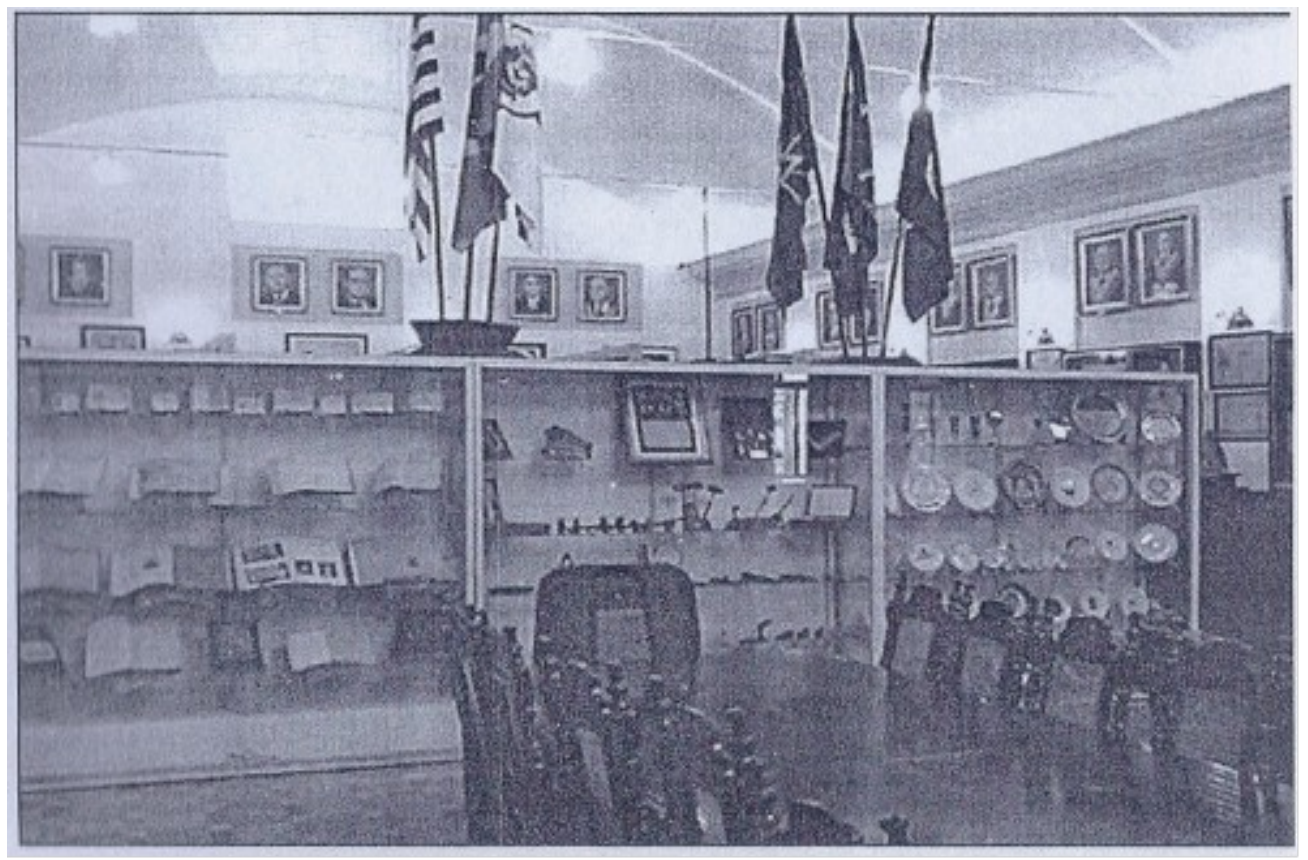

Fonte: FERREIRA, Cláudio Roque Buono, 2013. p. 65.

A grandeza arquitetônica do templo maçônico poderia ser admirada por qualquer um que passasse à frente do local, mas a suntuosidade interna do lugar estava restrita ao olhar e à admiração apenas dos membros da organização. O espaço englobava e ainda engloba cinco templos, biblioteca 
e um acervo composto por medalhas, brasões, bandeiras, aventais, estandartes, luvas, espadas, enfim, objetos destinados aos rituais reproduzidos e recriados na tradição maçônica (Figura 3). Vale ressaltar que as lojas Piratininga e América também reservaram espaços em seus templos com o mesmo propósito.

Na fachada do templo da loja América, no lado direito da Figura 4, é possível visualizar a fênix, ave que na mitologia grega simboliza renascimento. Conforme, a fábula, o pássaro, pouco maior que uma águia, com plumagens coloridas, após um século de existência, morre queimada pelos raios do sol e, transformado em cinzas. Das cinzas a ave retorna para completar um novo ciclo de vida. "A fênix maçonicamente, simboliza a iniciação, que é sinônimo de renascimento; simboliza, outrossim, a imortalidade” (CAMINO, 2010, p.175).

\section{Figura 4: Sede da Loja América}

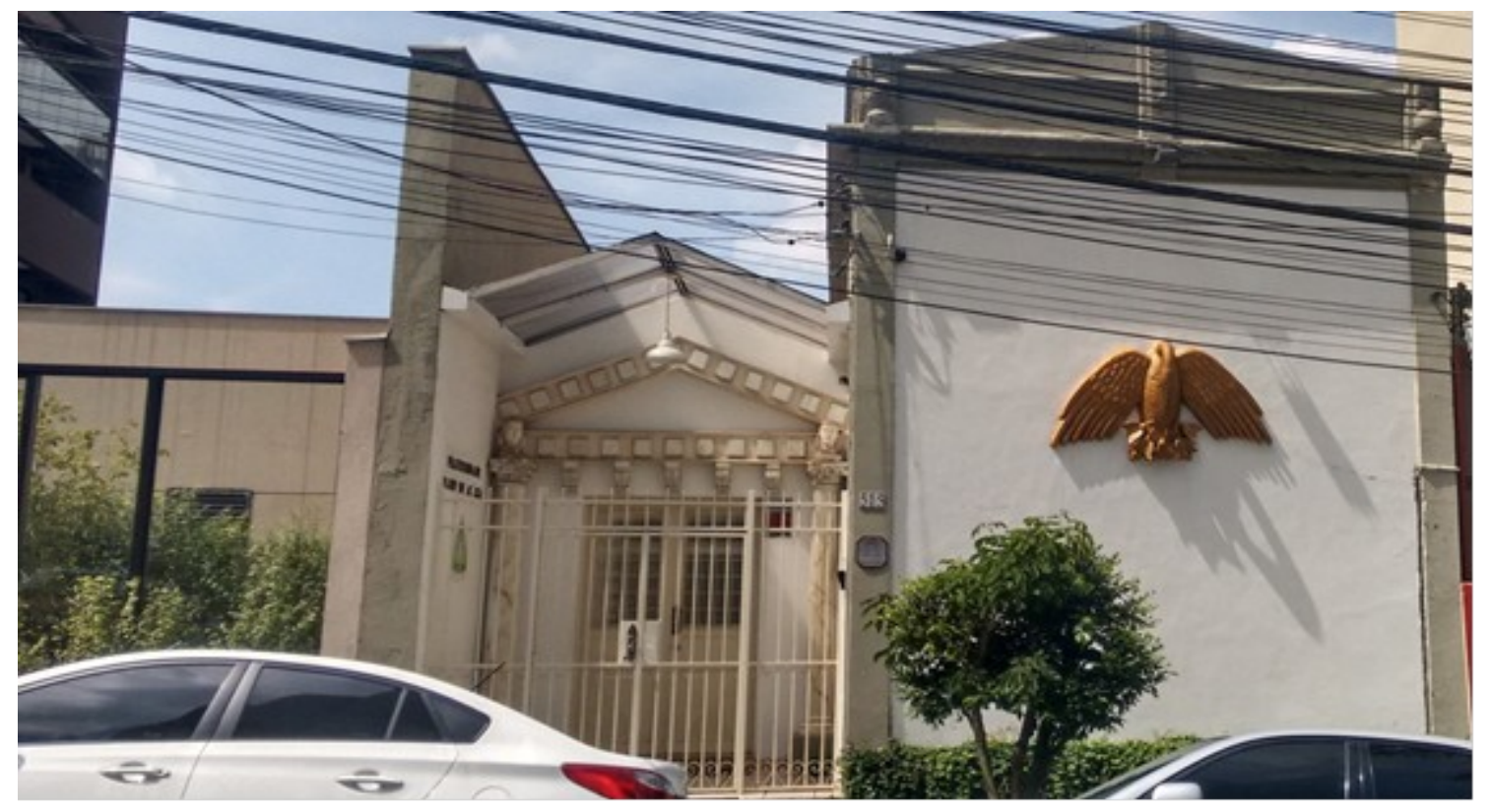

Fonte: Fachada do Templo da Loja América, Rua Apeninos, 2018. (Arquivo Pessoal). 
Figura 5: Galeria dos veneráveis históricos da Loja América.

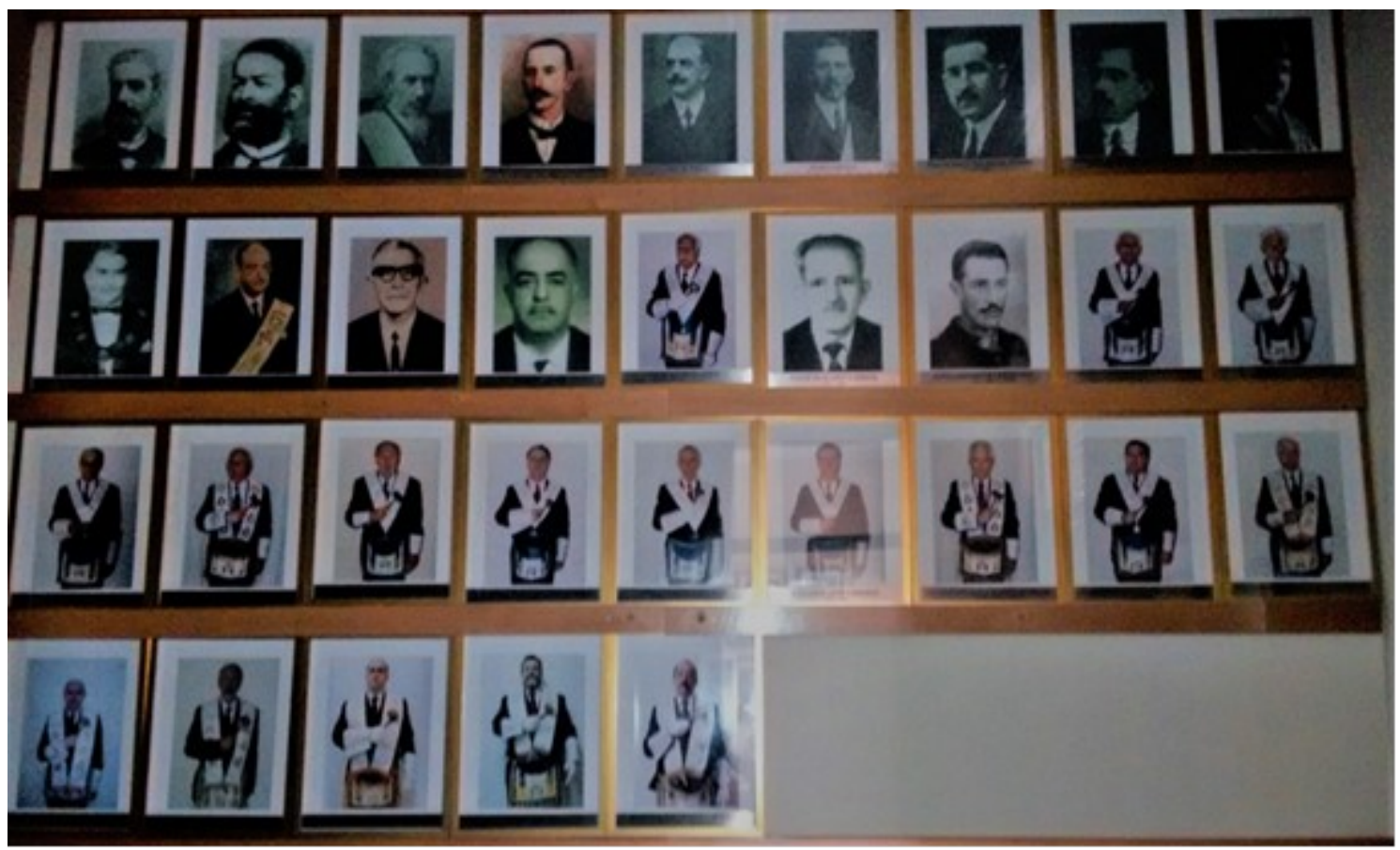

Fonte: Templo da Loja América, 2018. (Arquivo Pessoal).

Na figura 5 é possível ver na primeira fileira, do lado esquerdo, a imagem de Luiz Gama, segundo venerável da história da loja, antecedido por Américo Brasiliense e, sucedida pelo retrato de Américo de Campos. Na sala de reuniões da Loja, como se vê na Figura 6, outros membros históricos são homenageados.

\section{Figura 6: Sala de Reunião da Loja América}

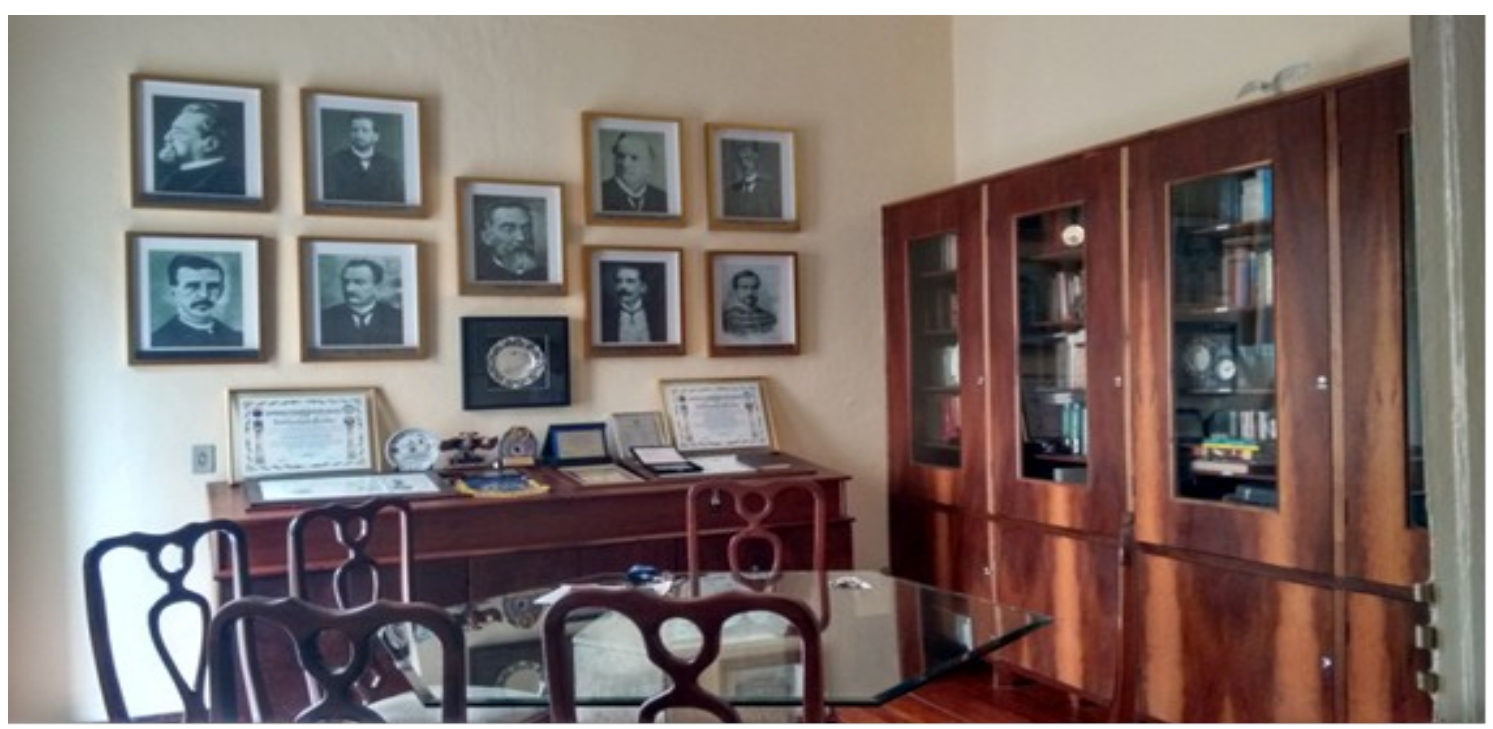


Fonte: Loja América, 2018 (Arquivo pessoal).

\section{Figura 7 Sala de Reuniões da Loja Piratininga}

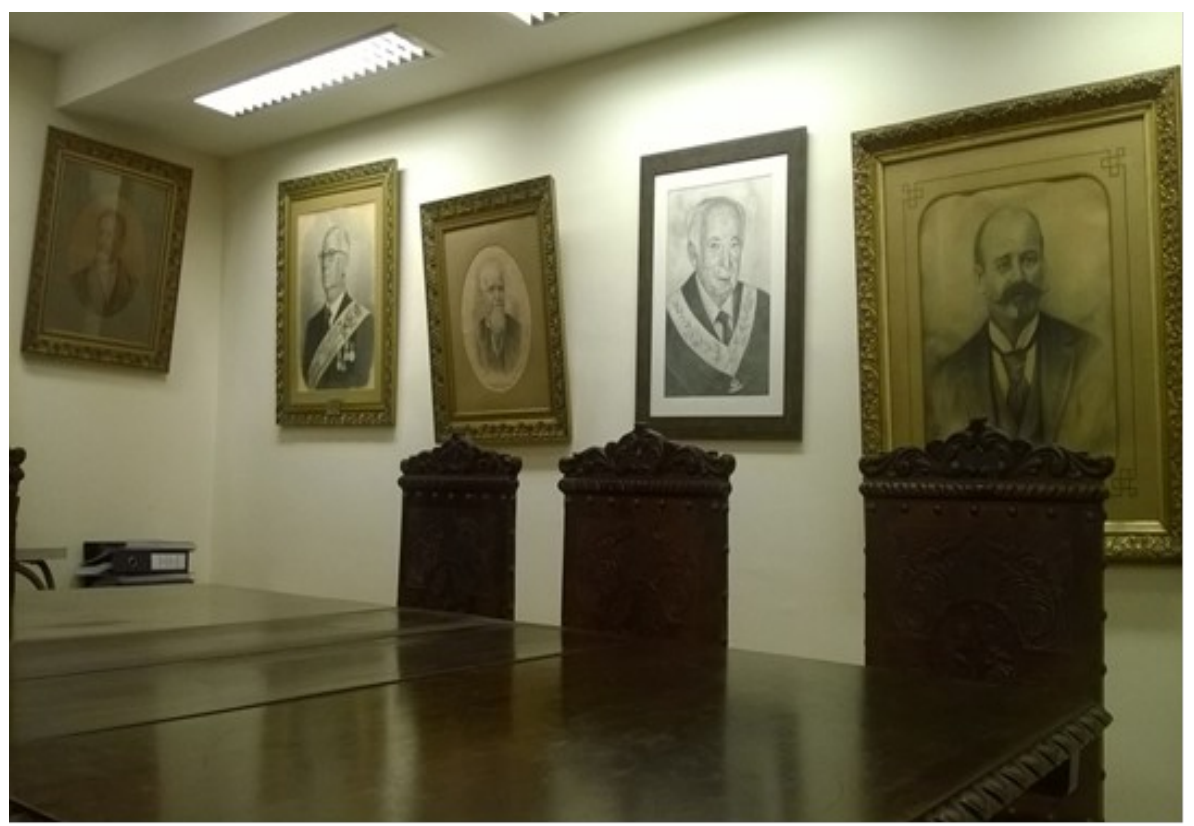

te: Loja Piratininga, 2016 (Arquivo pessoal).

Na Loja Piratininga os espaços também foram preenchidos com imagens dos membros históricos do templo. Na figura 7 nota-se que os retratos dos Irmãos afixados na parede, correspondem aos membros considerados ilustres na Loja (da esquerda para a direita Luiz Gama aparece em destaque, intercalada à imagem de Saldanha Marinho). Chama a atenção, particularmente, o fato dela ter homenageado Luiz Gama e Saldanha Marinho, Irmãos que não compunham o quadro da loja, ao passo que Antonio Bento, membro da mesma, se quer foi mencionado.

A imagem de Antonio Bento não mobilizou os membros da Loja Piratininga, na mesma proporção que Joaquim Ignácio Ramalho, membro fundador e uma das figuras mais evocadas na loja. Em homenagem a Irmão a loja encomendou um quadro com a imagem do Irmão em tamanho natural (vê na figura 8). 


\section{Figura 4.8 Joaquim Ignácio Ramalho}

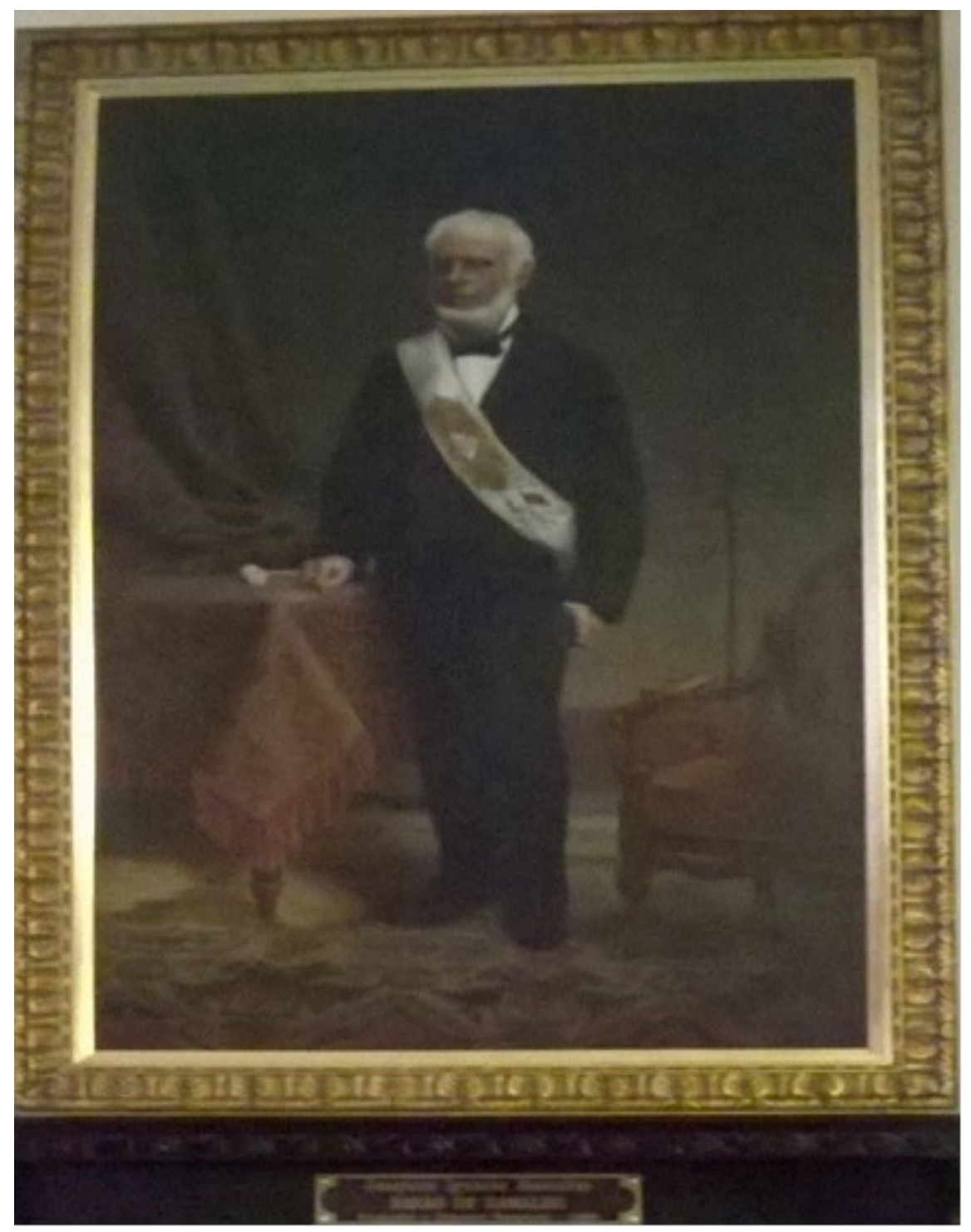

Fonte: Loja Piratininga, 2016. (Acervo pessoal)

A construção da memória maçônica da abolição dependeu não apenas das realizações e trajetórias individuais de cada membro, como se verifica, a evocação da memória dos Irmãos, deveria passar também pelo crivo das disputas internas e da popularidade do maçom. Considerados membros ilustres na Loja América, Joaquim Nabuco e Rui Barbosa, tiveram breve passagem pela organização, no entanto, por serem figuras populares entre os Irmãos, conseguiram assegurar que sua memória fosse contemplada na galeria de maçons históricos. 


\section{Figura 9 Destaques maçônicos da Loja América: Joaquim Nabuco e Rui Barbosa}

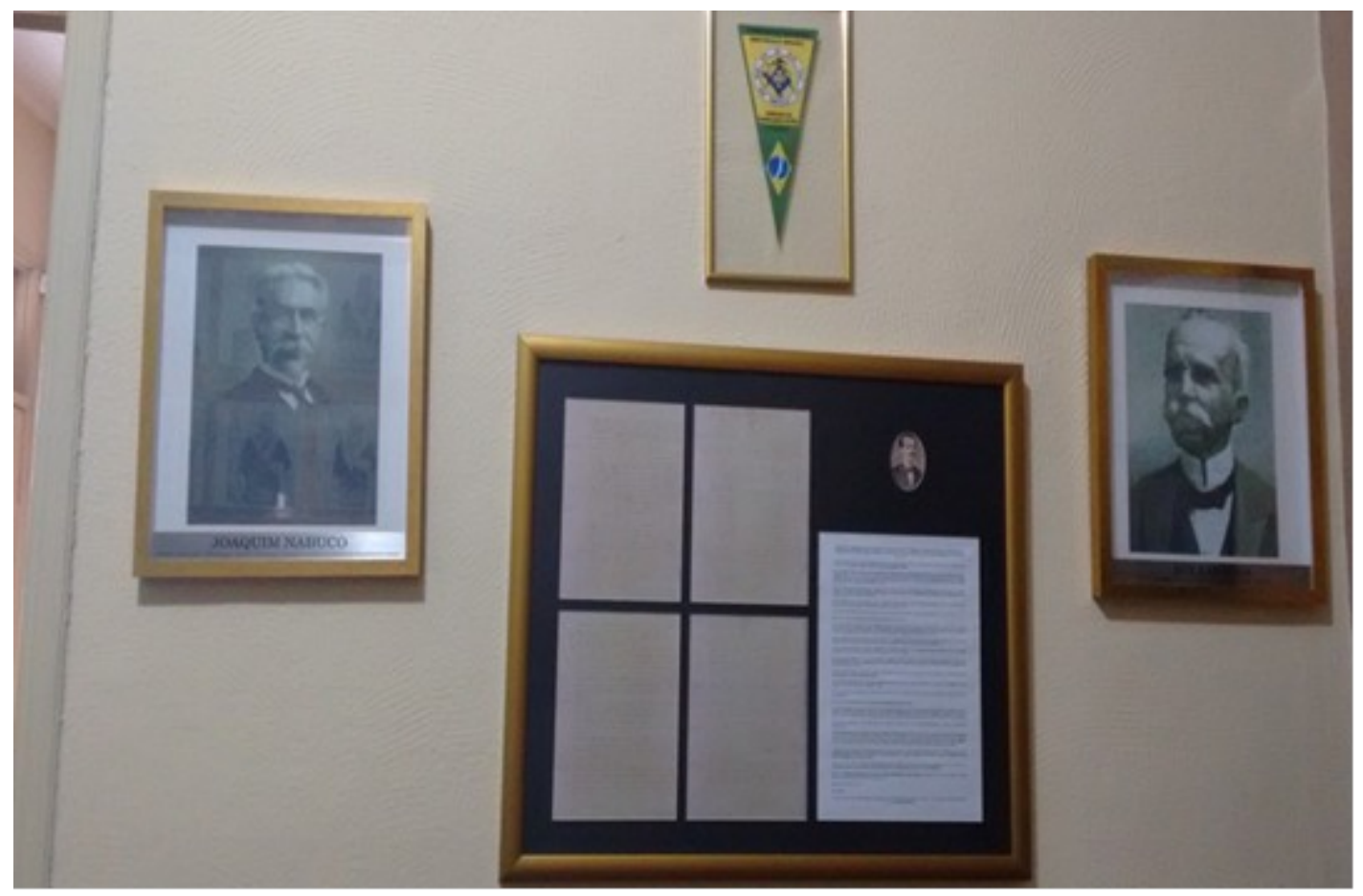

Fonte: Loja América, 2018 (Arquivo Pessoal).

Rui Barbosa afastou-se da maçonaria depois de seu retorno à Bahia e Joaquim Nabuco adormeceu em loja, ou seja, foi maçom inativo por muitos anos, até ser convidado a discursar pelo grão-mestre Saldanha Marinho, no Grande Oriente Unido, do vale dos Beneditinos em 1873, no contexto da Questão Religiosa (ver figura: 9).

\subsection{Memória da abolição nas páginas maçônicas}

O desejo de recriar um passado irretocável levou a organização maçônica a construir narrativas protagonizada pela própria instituição e seus agentes, nas páginas da história do país. Neste subtópico, o que se busca é compreender como a literatura maçônica celebrativa se constituiu, o papel que ocupou na construção da memória maçônica e o impacto gerado na historiografia de abolição.

A produção historiográfica denominada literatura celebrativa constituiu-se com as seguintes finalidades: combater o antimaçonismo fortemente ventilado com base na teoria do complô entre as décadas de 1930 a 1960 e reconstruir um passado glorioso para a maçonaria. 
Circunstancialmente, essa literatura celebrativa ganhou espaço e estímulo na década de 1970, durante a ditadura militar, quando se ensaiavam os preparativos para as celebrações do sesquicentenário de fundação do Grande Oriente do Brasil (primeira potência maçônica instalada no Brasil no ano de 1822). A partir de 1972, a produção de obras dedicadas ao tema ampliou-se consideravelmente. Destacam-se, nessa produção, os títulos: A maçonaria e a libertação dos escravos (1970); Os maçons que fizeram a história do Brasil (1973); Pequenas biografias de grandes maçons brasileiros (1973); A bucha, a maçonaria e o espírito liberal (1977); A maçonaria e sua política secreta (1981). Esses títulos tinham o propósito de forjar o protagonismo maçônico nos processos que culminaram na independência política do país, na abolição da escravidão e na implantação da República, passando por narrativas biográficas de personagens maçons, além, evidentemente, dos estudos dedicados a revelar as lendas ( GRAINHA, sd, p.37), simbologias, assim como os diversos ritos que comportavam a história da instituição, com a perspectiva de desmistificar a ideia de que a maçonaria era uma organização secreta, misteriosa e subversiva. Os pesquisadores maçons estavam seguros de que a participação maçônicas nos principais eventos históricos poderia ser facilmente convertida em protagonismo a partir da realização de alguns “ajustes” narrativos, dessa perspectiva surgiu a literatura celebrativa.

Constituída com atributos específicos, essa literatura celebrativa apresentava as seguintes características: 1) narrativas escritas apenas por pesquisadores maçons que em sua maioria, não possuía formação acadêmica; 2) literatura produzida majoritariamente com base em documentação proveniente de arquivos particulares das lojas maçônicas, cujo acesso, via de regra, esteve restrito à comunidade maçônica (MOREL; SOUZA, 2008, p.51); 3) abordagem celebrativa da literatura, pela falta de rigor e crítica em suas narrativas, haja vista o interesse maçônico em construir histórias que privilegiavam os aspectos profícuo da organização; 4) literatura celebrativa produzida por editoras maçônicas vinculadas às lojas; 5) estabelecimento de um diálogo com a historiografia antimaçônica, incorporando, inclusive, alguns aspectos dela.

Os escritores maçons concordavam convenientemente com a dimensão da teoria do complô de Barroso, que postulava a noção de que a maçonaria era uma organização forte, onipresente, responsável por protagonizar momentos decisivos da história do país, mas rejeitavam a dimensão do complô que via a maçonaria como organização agenciadora de um plano secreto interessado em promover a destruição do Estado e da Igreja. O pesquisador maçom D’Albuquerque, por exemplo, em seu livro A maçonaria e a libertação dos escravos, dialoga explicitamente com Gustavo Barroso, buscando extrair os elementos considerados eficientes para construir uma narrativa 
positiva da memória maçônica da abolição. D’ Albuquerque desenhava os caminhos a serem percorridos afim de reverter a teoria do complô em benefício da maçonaria, citando trechos da obra de Barroso, História Secreta do Brasil, no qual o escritor destaca a atuação de maçons no movimento abolicionista, sem a realização de uma análise crítica do livro.

Embora essa literatura celebrativa seja apreciável, para efeito de análise foi dada atenção especial aos estudos que dizem respeito ao tema desta pesquisa: a abolição. Por essa razão, optou-se pela abordagem às obras dos escritores maçons Nicola Aslan, Tenório D’Albuquerque e José Castellani, principais representantes dessas narrativas sobre o tema da abolição da escravidão. Tenório D’Albuquerque, em sua obra A maçonaria e a libertação dos escravos, centralizava sua análise na tentativa de comprovar que a organização assumiu posição de protagonismo em todas as etapas do processo que culminou com a abolição da escravidão. Conforme o autor,

A libertação dos escravos no Brasil, foi, não há como negar, iniciativa de maçons, um empreendimento da Maçonaria. A Maçonaria, cumprindo a sua elevada missão de lutar pela reivindicação dos direitos do Homem; de batalhar pela Liberdade, apanágio sagrado do Homem, empenhou-se sem desfalecimento, sem temor, em defesa pela emancipação dos escravos. Aí estão os fatos para confirmar a nossa assertiva. Basta ver a predominância extraordinária de maçons entre os que pelejaram para que desaparecesse do Brasil a vexatória mancha da escravidão. Dentre outros, citamos: Nabuco de Araújo, Visconde do Rio Branco, José do Patrocínio, Luiz Gama, Joaquim Nabuco, João Alfredo, Eusébio de Queiroz, Quintino Bocaiuva, Rui Barbosa, Teófilo Otôni, Saldanha Marinho, Luiz May, Chichorro da Gama, Pimenta Bueno (Marques de São Vicente), Sousa Franco, Barão de Rio Branco, Tristão de Alencar, Torres Homem, Francisco Otaviano, Figueira de Melo, Cristiano Otôni, Sinimbu, Jerônimo Sodré, Barros Pimentel, Nicolau Moreira (Presidente da Sociedade Brasileira Contra a Escravidão), Lopes trovão, Castro Alves, Ubaldino do Amaral, João Ferreira, Serpa Júnior (...) Antonio Prado (D’ALBUQUERQUE, 1970, p.29).

D’Albuquerque limitou-se a reproduzir trechos que interessassem à construção da memória da abolição maçônica. Em sua análise, evitou alcançar apreciações críticas sobre o modo como esses personagens eram apresentados pela historiografia. $\mathrm{O}$ autor superdimensionou nos traços ao relatar a atuação abolicionista de alguns maçons, e acrescentou informações inverídicas sobre outros. Sinimbu, embora, fosse citado por D’Albuquerque no trecho acima como maçom abolicionista, teria seguido como escravista até o fim da escravidão (MORAES, 1986, p.67). Outro exemplo ilustrado como maçom abolicionista pelo autor foi Antonio Prado, maçom da Loja Piratininga, que surge na análise do autor como um representante legítimo do abolicionismo em São 
Paulo. D’Albuquerque desconsiderou, no entanto, o fato de Antonio Prado ter aderido ao movimento abolicionista somente no ano de 1887 e ter sido um dos deputados que votou contra o projeto da Lei do Ventre Livre ( CONRAD, 1978, p.128).

O desejo maçônico de solidificar o protagonismo da organização no movimento abolicionista induziu muitos estudiosos a exagerarem a atuação de alguns maçons. Essa tentativa de ampliar a representatividade maçônica no processo abolicionista é notável, sobretudo, em relação à figura de Castro Alves. O poeta abolicionista foi um dos nomes mais evocados nas narrativas maçônicas celebrativas. Embora não houvesse consenso a respeito de sua trajetória na organização, reiteradas vezes, o abolicionista teve a sua figura exaltada. De acordo com D’Albuquerque, Castro Alves havia sido iniciado na Loja América em 1868 (D’ALBUQUERQUE, 1970, p.312) , ao passo que José Castellani sugere que Alves havia pertencido à Loja Amizade. Conforme relata Castellani:

Embora não haja comprovação, dada à criminosa destruição dos arquivos da loja “Amizade”, de São Paulo, é provável que nela tenha ocorrido a iniciação de Castro Alves, em 1868, quando estudava Direito, em São Paulo, numa época em que grande número de estudantes da Academia, engajados na campanha abolicionista, fazia parte das lojas maçônicas (CASTELLANI, 1973, p.39).

Essa sucessão de contradições e imprecisões indicava a ausência de fontes seguras que comprovasse os fatos. A literatura celebrativa foi construída muito mais baseada em suposições do que em acontecimentos. O difícil acesso a documentação maçônica resultou em "conhecimento escorregadio” (MOREL; SOUZA, 2008, p. 36). O exagero acabou, por vezes, sendo tomado como recurso a essa literatura celebrativa lapidada a partir da década de 1970.

A valorização das biografias nas narrativas maçônicas seguia com o propósito de atrelar a trajetória individual dos maçons ao movimento abolicionista. No livro do maçom Nicola Aslan, Pequenas biografias de grandes maçons brasileiros, esses elementos ficam evidentes. Elaborado em curto espaço de tempo, a obra trazia a biografia de 66 maçons. A lista, evidentemente, não contemplava a biografia de todos os Irmãos que haviam passado pela organização, destacava apenas a trajetória maçônica de membros considerados importantes, e que poderiam com isso alçá-la a um lugar de visibilidade na historiografia, na perspectiva da organização.

A literatura celebrativa propôs a escolha prévia de nomes, considerados legítimos para representar a organização. Na obra de Aslan, o interesse em compilar narrativas seletivas evidenciou-se logo no prefácio do livro. A maior preocupação, segundo o autor era "evitar incluir nestas micro-biografias figuras de maçons sobre os quais não tivéssemos dados positivos de sua 
qualidade maçônica” (ASLAN, 1973). O maçom encerrava o prefácio de seu trabalho sem esclarecer algumas questões importantes: 1) Quais seriam, afinal, as qualidades e as virtudes atribuídas aos maçons considerados exemplares nessas narrativas de memória?; 2) O que a maçonaria esperava dos “grandes maçons”?; 3) O que haveria de comum entre os biografados?

Todas essas indagações ficariam sem respostas nas narrativas de Aslan e nas de outros escritores. É possível inferir que o cuidado desses pesquisadores em propor uma seleção prévia de figuras a serem evocadas em suas narrações estivesse igualmente, relacionado ao fato de essa literatura ter sido produzida de forma substancial no contexto da ditadura militar, estado de exceção que, certamente, imputou limites a ela.

O cenário político influenciaria na compilação dessa literatura, determinando o seu delineamento, sem impor-se, contudo, como único elemento a nortear a produção dessa historiografia. Outros aspectos certamente seriam levados em consideração pelos escritores maçons para justificar as escolhas das figuras que seriam selecionadas para representar a memória maçônica da abolição, como por exemplo, “as qualidades maçônicas”.

As denominadas “qualidades maçônicas” dos biografados, referidas por Aslan, embora não fossem assim classificadas em seu estudo, permite algumas conjecturas. É possível crer que o autor tenha considerado como "qualidades maçônicas" elementos ajuizados no tempo presente e não arroladas a partir dos valores maçônicos imputados no passado, implicando, portanto, na construção de narrativas dominadas, na maior parte das vezes, por anacronismos e juízo de valores edificados pós-fato. Ao tentar redesenhar o passado maçônico nas páginas da história da organização, esses estudiosos fariam desaparecer das narrativas as biografias de Irmãos contrários à abolição da escravidão, pois, afinal, não interessava à maçonaria vincular a biografia de maçons ou, tampouco, associar a sua imagem à escravidão.

A memória da abolição maçônica paulista não poderia ser construída com base em narrativas vinculadas à instituição escravista. Nos últimos anos de vigência da escravidão no Brasil, o debate sobre a iniciação de senhores de escravos foi tema de discussão em diversas sessões maçônicas. A Loja Piratininga, no ano de 1887, chegou a elaborar projeto que previa a multa a todos os Irmãos que tivessem escravos e impedindo, ao mesmo tempo, a iniciação de candidatos escravocratas. É provável que, na prática, esse projeto não tenha saído do papel, uma vez que nas atas produzidas pela Loja Piratininga não há apontamentos de maçons sendo multados por serem proprietários de escravos, assim como não há evidências de candidatos à iniciação sendo barrados por possuírem cativos. 
O debate contra a propriedade escrava, embora tenha sido tema de discussão nas sessões, não gerou mudança de comportamento de seus membros. Pelo contrário, o que se discutiu a respeito da extinção da escravidão no templo foi que ela se estendesse o maior tempo possível, e para os maçons isso significava colocar um ponto final na escravidão em 1890, dois anos depois do que de fato ocorreu com a assinatura da Lei Áurea em 1888. Nos bastidores maçônicos nota-se uma profunda resistência dos Irmãos em fechar uma agenda contra a escravidão. Até os últimos dias os maçons resistiram pelo direito da propriedade escrava.

Seguramente, as narrativas maçônicas omitiriam a presença dos maçons senhores de escravos, contudo, não bastava à literatura celebrativa condenar a escravidão. Era preciso, sobretudo, forjar um protagonismo maçônico no desmonte do sistema escravista por meio de seus agentes, demonstrando a importância da organização em todas as etapas do processo que culminou com o fim da escravidão, do princípio ao fim. Nesse sentido, as narrativas maçônicas desempenhariam a função de arquitetar essas histórias, "recrutando” entre os abolicionistas mais proeminentes da historiografia da abolição aqueles que melhor sustentariam essas narrativas.

$\mathrm{Na}$ tentativa de procurar pelas “qualidades maçônicas” de seus biografados, os pesquisadores maçons manteriam na penumbra personagens que pudessem simbolizar ou serem porta-vozes de valores então rejeitados no presente como a escravidão. Por essa razão, buscariam celebrar apenas as "qualidades maçônicas” de figuras públicas, que haviam compartilhado de discursos e práticas antiescravistas. Por essa razão, nomes como os de Luiz Gama, Antonio Castro Alves, Joaquim Nabuco e Rui Barbosa tiveram lugar privilegiado nessas narrativas.

Rui Barbosa tornou-se figura cara às narrativas maçônicas produzidas na década de 1970, sobretudo porque propôs um dos principais projetos à emancipação dos escravizados no círculo maçônico, em 4 de abril de 1870 na Loja América. Na ocasião, Rui Barbosa era apenas um estudante da Academia de Direito. Com o apoio de Luiz Gama, propôs um projeto que previa a criação de um fundo maçônico que assegurasse o alforriamento de crianças escravas do sexo feminino menores de sete anos. O documento, enviado ao Grande Oriente do Brasil (dos Beneditinos), não chegou a sair do papel, mas ficaria cristalizado nas memórias maçônicas como uma das principais medidas de antecipação maçônica à Lei do Ventre Livre.

Superestimada pelas narrativas maçônicas, a proposta de Rui Barbosa, tal como foi ventilado, demonstrava ter sido parte da premissa de que a concepção do projeto da Lei do Ventre Livre tinha nascido no círculo maçônico quando, na verdade, havia sido fruto de largo debate travado no parlamento e com ampla contenda e participação nacional de setores civis e da imprensa 
(CONRAD, 1978, 112-113). De acordo com Robert Conrad, “os jornais do Rio de Janeiro e das províncias voltavam crescentemente sua atenção para a controvérsia à medida que o debate legislativo prosseguia, semana após semana” (CONRAD, 1978, p.117).

O projeto de Rui Barbosa, embora não fosse original e não tivesse saído do papel, acabou eclipsando o plano proposto, anteriormente, pelos maçons Ubaldino do Amaral e José Leite Penteado, da Loja Perseverança III, de Sorocaba, em 19 de julho de 1869. Ambos sugeriram a criação de um fundo afim de assegurar a libertação de meninas menores de sete anos que ficariam respectivamente sob a proteção de suas lojas (CASTELLANI; CARVALHO, 2009, p.121). Provavelmente, o projeto proposto por Rui Barbosa tenha ganhado maior visibilidade nas narrativas maçônicas em razão de ele ter ocupado lugar de relevo na vida pública comparada a trajetória política de Ubaldino do Amaral.

Nas narrativas maçônicas Joaquim Nabuco surgiu como personagem incansável que havia lutado arduamente no Parlamento, arregimentando apoio entre os correligionários para a assinatura da Lei Áurea, em 13 de maio, ao passo que Luiz Gama aparecia nessas narrativas como um nome importante na luta pela libertação de africanos ilegalmente escravizados em âmbito jurídico.

Tratava-se de uma estratégia maçônica lançar luz apenas sobre a biografia, deixando de lado, as narrativas das trajetórias de maçons pouco conhecidos, até mesmo daqueles que haviam participado, de alguma maneira, das ações abolicionistas. Os personagens com maior visibilidade pública seriam lançados a um lugar privilegiado da memória maçônica da abolição, ao passo que outros seriam esquecidos. Muitos deles esquecidos por suas escolhas ideológicas distintas dos demais membros da organização, ou até mesmo, por terem construído relações conflituosas com seus congêneres maçônicos.

A historiografia da abolição paulista está repleta de personagens cujas identidades maçônicas foram subtraídas, apagadas, parcial ou completamente, da memória maçônica. Nas atas das Lojas América e Piratininga encontram-se figuras popularizadas nas narrativas da abolição tal qual Albino Soares Bairão, Jaime Serva, Salvador de Mendonça, Ferreira de Menezes, Olimpio da Paixão, Justo Nogueira de Azambuja, Antonio Arcanjo Dias Batista, João Fernandes Junior, Azevedo Marques e Antonio Louzada, em ações solidárias junto aos dois principais líderes do abolicionismo paulista, Luiz Gama e Antonio Bento, que não encontraram espaço nas narrativas maçônicas (AZEVEDO, 2010, 108). Alguns, entretanto, ganhariam uma nova oportunidade de serem inseridos à historiografia da abolição com a revisitação de suas biografias. Ferreira de Menezes, por exemplo, foi abolicionista iniciado na Loja Piratininga, filiado à Loja Sete de 
Setembro e depois à Loja América. O maçom teve recentemente sua trajetória tomada como tema de pesquisa de Ana Flávia Magalhães Pinto, Fortes laços em linhas rotas: literatos negros, racismo e cidadania na segunda metade do século XIX, tese defendida em 2014 (PINTO, 2014). Nesse estudo, a autora abordou a experiência abolicionista do jornalista, salientando a sua experiência na organização maçônica.

Estudante da Academia de Direito em São Paulo, Ferreira de Menezes, ao lado de Luiz Gama, advogou em ações de liberdade, em nome da Loja América. O maçom atuou como redator no jornal Radical Paulistano. Ao retornar para a Corte, atuou em diversos periódicos, fundando na sequência a folha abolicionista Gazeta da Tarde em sociedade com José do Patrocínio. O jornal se tornou uma das folhas abolicionistas mais importantes da imprensa carioca (PINTO, 2014), ainda assim, Ferreira de Menezes sequer foi mencionado na literatura celebrativa produzida na década de 1970, ao passo que nomes como os de Joaquim Nabuco e Rui Barbosa, que tiveram breve passagem pela maçonaria, seriam, em contrapartida, exaltados pelas narrativas de Nicola Aslan e de José Castellani por serem personagens de grande notoriedade.

Essa produção bibliográfica maçônica definiu a literatura maçônica celebrativa assentada na ideia de que os grandes personagens pudessem ser capazes individualmente de serem agentes determinantes da transformação da sociedade de um tempo histórico. Pensar a história maçônica com base na biografia de poucos homens limitaria, sem dúvida, a compreensão sobre o alcance real que teve a organização. Esse viés analítico que lança luz sob um único prisma dos grandes homens afastava de suas narrativas a história de homens e mulheres que passaram pela organização, mas não participaram da cena política.

Essa literatura celebrativa, que predominou no período de 1970 a 1990, tencionava atingir não apenas o leitor maçom, mas o grande público. Contudo, a partir da década de 1990, perderia força diante da inserção do tema na universidade. O silêncio da academia em relação ao assunto entre as décadas de 1940 a 1990 foi cuidadosamente discutido por Célia Maria Marinho de Azevedo em seu livro Maçonaria, anti-racismo e cidadania. Segundo a autora, esse posicionamento refletia uma historiografia marcadamente refratária à incorporação do tema maçonaria (AZEVEDO, 2011). A começar pela análise interpretativa de Caio Prado Júnior, em sua obra A formação do Brasil contemporâneo. O trabalho, publicado em 1942, questionava o papel de protagonismo desempenhado pela maçonaria na destituição do sistema colonial. Para o autor, a maçonaria, havia sido mero instrumento a serviço das elites políticas, interessadas em promover as grandes transformações políticas do país. Segundo ele, independentemente do apoio ou não da maçonaria, as 
elites teriam realizado tais mudanças. Na análise de Sérgio Buarque de Holanda também se observa uma tentativa de diminuir a importância civil da organização maçônica. De acordo com o autor, “a importância da maçonaria durante o Império prendia-se largamente ao papel que puderam os maçons desempenhar nas origens da independência do país” (HOLANDA, 1997, p.334). Ainda que considerasse a participação maçônica no processo que culminou com a independência, o historiador não via a organização como motor desse processo, assim como, não via relevância na ação dela nos acontecimentos históricos subsequentes, como a Abolição e a República. Para Buarque, a organização maçônica havia sucumbido perante a emergência do positivismo na década de 1850 (HOLANDA, 1997). Segundo Azevedo, essas interpretações foram essenciais para impedir o avanço de estudos sobre a maçonaria no Brasil.

As barreiras que separavam a literatura celebrativa da produção acadêmica seriam finalmente rompidas com os primeiros estudos acadêmicos, realizados na década de 1990. Destacase, nesse sentido, os trabalhos de Alexandre Mansur Barata. O autor abordou o tema maçonaria em sua dissertação de mestrado, Luzes e Sombras: a ação dos pedreiros-livres brasileiros, oferecendo importantes contribuições ao estudo do tema (BARATA, 1999).

O grande mérito do estudo realizado por Barata assenta-se no fato do pesquisador ter se desvencilhado da literatura celebrativa para debruçar-se sobre rico material de domínio público, composto por constituições, jornais, dicionários de termos maçônicos, circulares e cartas trocadas entre as obediências maçônicas, encontradas em arquivos e bibliotecas públicas. Por meio dessa vultosa documentação, o autor ofereceu ao estudo do tema novas perspectivas analíticas, novas fontes e novas abordagens.

O estudo de Barata representou a reintrodução do tema maçônico na academia. Logo outros estudos importantes sobre o assunto seriam produzidos. O corolário dessa fissura refletiria ademais sobre a literatura celebrativa maçônica, visto que um novo grupo de pesquisadores maçons se dedicaria à produção acadêmica, sem deixar inteiramente de lado a literatura celebrativa. Essa produção literária não desapareceria completamente, continuaria sendo cultivada, embora não com a mesma intensidade, em paralelo à produção acadêmica. José Castellani, um dos principais representantes da literatura celebrativa, por exemplo, seguiu produzindo ininterruptamente desde seu primeiro título publicado em $1973^{5}$.

5 O autor publicou os seguintes títulos CASTELLANI, José. Os maçons que fizeram a História do Brasil. São Paulo: A Gazeta Maçônica, 1973; —_ Shemá Israel. São Paulo: A Gazeta Maçônica, 1977; A ciência maçônica e as antigas civilizações. São Paulo: Editora Universitária, 1977; —_ _ São Paulo na década de trinta. São Paulo: Editora Policor, 1978; __ A maçonaria e sua política secreta. São Paulo: Traço Editora, 1981; , Origens do misticismo na maçonaria. São Paulo: Traço Editora, 1982;

Grau de aprendiz maçom. São Paulo: Editora A Gazeta Maçônica, 1985; , Liturgia e Ritualística do , A Maçonaria moderna. São Paulo: 
Frederico Guilherme Costa representa o novo grupo de pesquisadores maçons que tem produzido estudos vinculados à universidade, e que teve o devido cuidado de utilizar fontes substanciais e seguras. Costa valeu-se de documentos encontrados em arquivos públicos, como boletins, constituições maçônicas e correspondências trocadas entre lojas maçônicas. Todavia, é possível encontrar em sua análise ainda alguns resquícios da literatura maçônica celebrativa. O autor não deixou de evocar a ideia de que a organização maçônica fosse harmônica, destituída de conflitos e não fosse alvo de disputas por poder entre os próprios Irmãos.

A organização maçônica instrumentalizou inúmeros recursos com o intuito de impor sua força social, política e simbólica fora do círculo maçônico, consolidando a produção de uma ampla literatura maçônica celebrativa, produzida por historiadores maçons a fim de produzir uma narrativa vencedora, na qual a abolição da escravidão fosse compreendido como um movimento protagonizado pela organização.

\section{Referência Bibliográfica}

ASLAN, Nicola. Pequenas biografias de grandes maçons brasileiros. Paraná, Londrina: A Trolha, 1973.

Maçonaria, Anti-racismo e Cidadania: uma história de lutas e debates transnacionais. São Paulo: Annablume, 2010.

AZEVEDO, Elciene. Orfeu de carapinha: a trajetória de Luiz Gama na imperial cidade de São Paulo. Campinas, São Paulo: Editora da Unicamp, Centro de Pesquisa em História Social da Cultura, 1999.

Antonio Bento, homem rude do sertão: um abolicionista nos meandros da justiça e da política. In: Locus: Revista de História. Juiz de Fora. 2007. Vol. 13, p.123-143.

O direito dos escravos: lutas jurídicas e abolicionismo na província de São Paulo. Campinas, São Paulo: Editora da Unicamp, 2010.

. Luzes e sombras: a ação da Maçonaria Brasileira (1870-1920). Campinas, São Paulo: Editora Unicamp, Centro de Memória Unicamp. (Coleção Tempo e Memória), 1999.

A Gazeta Maçônica, 1986; , Liturgia e Ritualística do grau de companheiro maçom. São Paulo: A Gazeta Maçônica, 1987; , Consultório maçônico. Londrina: Editora Trolha (1987); , Liturgia e Ritualística do grau de mestre maçom. São Paulo: A Gazeta Maçônica, 1987; Trolha, 1988; , José Bonifácio: um homem além do tem , O rito escocês antigo e aceito. Londrina: A mestre instalado. São Paulo: A Gazeta Maçônica, 1989; São Paulo: A Gazeta Maçônica, 1988; , O Trolha, 1989; , A maçonaria e o movimento republicano brasileiro. São Paulo: Traço Editora, 1989

Consultório maçônico. Londrina: A Trolha, 1990; Dicionário Etimológico Maçônico.Londrina: Editora Trolha, 1990; Maçonaria Moderna: a Liberdade Revelada. Londrina: A Trolha, 1991; históricas e místicas do templo maçônico. São Paulo: A Gazeta Maçônica, 1991; História do Grande Oriente de São Paulo. Brasília: Grande Oriente do Brasil, 1994; Londrina: A Trolha, 1998. 
BARROSO, Gustavo. A história secreta do Brasil. Porto Alegre, Rio Grande do Sul: Coleção Comemorativa do Centenário de Gustavo Barroso, 1993. vol. 5.

BEOZZO, José Oscar. A Igreja e a revolução de 1930, o Estado Novo e a Redemocratização. In: (Org) FAUSTO, Boris. História Geral da Civilização Brasileira. O Brasil republicano. São Paulo: Difel, 1984. Tomo 3. vol. 4.

CASTELLANI, José. Os maçons que fizeram a história do Brasil. São Paulo: Editora A Gazeta Maçônica, 1973.

A Maçonaria e sua política secreta. São Paulo: Traço Editora, 1981.

1994.

História do Grande Oriente de São Paulo. Brasília: Grande Oriente do Brasil,

. Piratininga: história da loja maçônica tradição de São Paulo. Edição comemorativa do ano do Sesquicentenário. São Paulo: OESP, 2000.

CASTELlani, José; CARVAlHO, Willian Almeida. História do Grande Oriente do Brasil: a maçonaria na história do Brasil. São Paulo: Madras, 2009.

COSTA, Frederico Guilhermo. A maçonaria e a emancipação do escravo. Londrina, Paraná: Editora Maçônica a Trolha, 1999.

FERREIRA, Cláudio Roque Buono. Maçonaria e Museu II. São Paulo: Madras, 2013.

GOHL, Jefferson William. O real e o imaginário: a experiência da maçonaria na Loja União III em Porto União da Vitória - 1936 a 1950.

GRAINHA, Manuel Borges. História da Franco-maçonaria em Portugal (1733-1912). $4^{\circ}$ Ed. Tradução: Antônio Carlos de Carvalho. Coleção Janus, Lisboa: Vega, s.d.

HOBSBAWM, Eric \& RANGER, Terence. (Org). A invenção das tradições. Tradução Celina Cardim Cavalcanti. São Paulo: Paz e Terra, 2012.

Da maçonaria ao positivismo. (Org.) Sérgio Buarque de Holanda. In: História Geral da Civilização Brasileira. $8^{\circ}$ Edição. Rio de Janeiro: Bertrand Brasil, 2008. vol. 7, p. 334.

OLIVEIRA, Cecilia Helena de Salles. Museu Paulista: espaço celebrativo e memória da Independência. In: Memória e (res)sentimento: indagações sobre uma questão sensível. (Org) Stella Bresciani e Márcia Naxara. $2^{\circ}$ Ed. São Paulo, Unicamp: Editora Unicamp, 201, p. 195-219. 1934.

SANTOS, Dario Nogueira dos. A maçonaria e a Ação Integralista Brasileira. Paranaguá,

SEIXAS, Jacy Alves de. Percursos de memórias em terras de história: problemáticas atuais. In: Memória e (res) sentimento: indagações sobre uma questão sensível. (Org) Stella Bresciani e Márcia Naxara. 2.ed. São Paulo, Campinas: Editora Unicamp, 2004, p. 40-41.

SILVA, Tiago Cesar. Para além de esquadros e compassos: a construção da memória 
maçônica no Brasil. Universidade Federal do Estado do Rio de Janeiro. Programa de PósGraduação em memória social. Rio de Janeiro, 2012.

\section{Endereços eletrônicos:}

Elizabeth do Val. Breve resumo da História da Construção do Edifício_Sede do Grande Oriente de São Paulo e da formação do Museu Maçônico.www.gosp.org.br/wp_content/uploads/2016/08/Edificio_Sede_GOSP_e_Museu.pdf. $<$ Acessado em 16/08/2016>.

Portal.mackenzie.br/imprensa/noticias/arquivo/artigo/

OAB_concede_titulo_ao_lider_gama_no_mackenzie/, <Disponibilizado em dezembro de $15 / 05 / 2018>$ 